\title{
Pediatric Multiple Sclerosis in Portugal: A Multicentre Study
}

\section{Esclerose Múltipla Pediátrica em Portugal: Um Estudo Multicêntrico}



\author{
Ana Sofia CORREIA 1 , Luís AUGUSTO², Joana MEIRELES ${ }^{3}$, Joana PINTO ${ }^{4}$, Ana Paula SOUSA $\rrbracket^{5}$ \\ Acta Med Port 2016 Jul-Aug;29(7-8):425-431 - http://dx.doi.org/10.20344/amp.6346
}

\section{ABSTRACT}

Introduction: Multiple sclerosis is most often diagnosed among young adults but less frequently it may present during childhood or adolescence. In Portugal, there has been only one previous single-center, pediatric multiple sclerosis study. The main objective was the evaluation of the demographic, clinical, laboratorial and neuroradiological characteristics of patients with pediatric-onset multiple sclerosis in Portugal. The secondary objectives were to compare the characteristics of childhood-onset multiple sclerosis and adolescent-onset multiple sclerosis and to characterize the treatments prescribed.

Material and Methods: We performed a retrospective observational, multicentric study. We reviewed data of all patients with multiple sclerosis younger than 18 years at the onset of their first multiple sclerosis symptoms.

Results: There were 46 patients $(72 \%$ female) included with a mean age at diagnosis of 16.1 years. Six cases had childhood-onset and 40 cases had adolescence-onset. The median value of Expanded Disability Status Scale was two. Relapsing-remitting multiple sclerosis was most prevalent ( $98 \%$ of cases). In the cerebrospinal fluid study, $74 \%$ of patients had positive oligoclonal bands. Brain magnetic resonance imaging studies showed a predominant supratentorial involvement ( $98 \%$ of cases), whereas the cervical segment was the most frequently affected in the spinal cord. All the patients enrolled in the study underwent immunomodulatory therapy, $75 \%$ of patients with beta-interferon. Concerning differences between the childhood and the adolescent groups, we found a greater proportion of male patients and of individuals with cerebrospinal fluid pleocytosis among the childhood-onset group.

Discussion: This study provides new data on pediatric multiple sclerosis characteristics in Portugal and our results are similar to previously reported data in other parts of the world

Conclusion: This is the first multicentric study characterizing pediatric multiple sclerosis in Portugal. The mechanisms underlying the particularities of pediatric multiple sclerosis remain largely unknown and further studies are required.

Keywords: Adolescent; Child; Multiple Sclerosis; Portugal.

\section{RESUMO}

Introdução: A esclerose múltipla é habitualmente diagnosticada em adultos jovens mas, mais raramente, pode manifestar-se durante a infância ou adolescência. Os dados sobre a esclerose múltipla pediátrica em Portugal são escassos. O objectivo principal deste estudo é a avaliação das características demográficas, clínicas, laboratoriais e neurorradiológicas da esclerose múltipla de início em idade pediátrica em Portugal. Os objetivos secundários consistem na comparação entre a esclerose múltipla de início na infância e a esclerose múltipla de início na adolescência e na caracterização dos tratamentos prescritos.

Material e Métodos: Realizou-se um estudo retrospectivo, observacional e multicêntrico, que consistiu na análise dos dados de todos os doentes com apresentação da EM antes dos 18 anos.

Resultados: Incluíram-se 46 doentes ( $72 \%$ do sexo feminino), com uma idade média de diagnóstico de 16,1 anos. Seis casos tiveram início na infância, 40 na adolescência. A esclerose múltipla apresentou-se em $98 \%$ dos casos com a forma surto-remissão. O estudo do líquor revelou bandas oligoclonais em $74 \%$ dos doentes. A ressonância magnética encefálica mostrou predominantemente lesões supratentoriais (98\% dos casos), enquanto que a ressonância medular revelou que o segmento cervical foi o mais frequentemente afectado. Todos os doentes iniciaram terapêutica imunomoduladora ( $75 \%$ com interferão $\beta)$. Relativamente às diferenças entre os dois grupos etários, encontrámos uma maior proporção de doentes do sexo masculino e com pleocitose no grupo com apresentação na infância.

Discussão: Este trabalho fornece novos dados sobre as características da esclerose múltipla pediátrica em Portugal e os resultados são semelhantes aos reportados em outras partes do mundo.

Conclusão: Este é o primeiro estudo multicêntrico português sobre a esclerose múltipla com apresentação na infância e adolescência. Mais estudos são necessários para clarificar os mecanismos subjacentes às particularidades da esclerose múltipla pediátrica.

Palavras-chave: Adolescente; Criança; Esclerose Múltipla; Portugal.

\section{INTRODUCTION}

Multiple sclerosis (MS) is a chronic inflammatory and neurodegenerative disease of the central nervous system (CNS). MS onset before the age of 18 years occurs in up to $10 \%$ of all cases ${ }^{1,2}$ Historically, pediatric MS has been

diagnosed using adult criteria and treated using adult paradigms. Nevertheless, over the last years, knowledge about pediatric MS has increased substantially.

Despite a longer time interval from disease onset to

\footnotetext{
1. Neurology Department. Centro Hospitalar de Lisboa Ocidental. Lisboa. Portugal.

2. Neurorradiology Department. Centro Hospitalar São João. Porto. Portugal.

3. Neurology Department. Centro Hospitalar São João. Porto. Portugal.

4. Neurorradiology Department. Centro Hospitalar e Universitário de Coimbra. Coimbra. Portugal.

5. Neurology Department. Centro Hospitalar de Setubal. Setubal. Portugal.

$\triangle$ Autor correspondente: Ana Paula Sousa. apdiogosousa@gmail.com

Recebido: 25 de fevereiro de 2015 - Aceite: 16 de outubro de 2015 | Copyright $\odot$ Ordem dos Médicos 2016
} 
secondary progression, patients with childhood-onset MS reach irreversible disability at a younger age than patients with adult-onset $\mathrm{MS}^{3}$ and the early disease onset may have an important impact on psychosocial development, school performance and professional education. An early diagnosis is also critical because of the implications in later life. As children and adolescents with MS are at risk of serious cognitive and physical sequelae, significant resources and efforts should be directed towards the care and study of pediatric patients and clinicians should consider the opportunity of initiating early disease-modifying treatment.

In Portugal, MS prevalence is around 56.2/100,000. ${ }^{4}$ Concerning pediatric MS, there has been only one previous single-center Portuguese study from Porto, consisting of the clinical characterization of 17 patients with young onset MS (defined as presentation of symptoms before 21 years). ${ }^{5}$ According to that study, $9.2 \%$ of patients with MS had young onset disease. Consequently, it is necessary to obtain an accurate gauge of pediatric MS characteristics (demographic, clinical, laboratorial and neuroradiological) in Portugal.

\section{OBJECTIVES}

The main objective of our study was the evaluation of the demographic, clinical, laboratorial and neuroradiological characteristics of patients with pediatric-onset MS. The secondary objectives were to compare the characteristics of childhood-onset MS (< 12 years) and adolescent-onset MS (12 - 18 years), and to characterize the treatments prescribed to pediatric MS patients in Portugal.

\section{MATERIAL AND METHODS}

This is an observational, retrospective and multicenter study. Patients were recruited at four Portuguese hospitals from Lisbon, Coimbra and Porto (Centro Hospitalar de Lisboa Ocidental, Centro Hospitalar de Lisboa Central, Centro Hospitalar e Universitário de Coimbra, and Centro Hospitalar São João).

\section{Population}

As an exploratory study, we included all the patients who fulfilled the inclusion criteria: patients with MS according to the International Pediatric Multiple Sclerosis Study Group criteria, ${ }^{6}$ younger than 18 years at the onset of their first MS symptoms, with medical recordings in the participating hospitals.

\section{Procedures}

We reviewed the medical records of the patients and collected the data through 2012, including 1) demographic characteristics: gender, ethnicity; 2) clinical data: age at first symptoms attributed to MS, age at confirmation of MS diagnosis, disease course at presentation (relapsingremitting or progressive), time interval between the first two neurologic episodes, age of conversion to secondary progressive course, time of follow-up, Expanded Disability Status Scale (EDSS) score at first consultation and at the last one, time to Expanded Disability Status Scale (EDSS) score of 4, family history of MS; 3) laboratorial data: oligoclonal bands (OCBs) in the cerebrospinal fluid (CSF), CSF IgG index, CSF white-cell count, varicella zoster virus and herpes simplex virus seropositivity in serum; 4) characteristics of the first magnetic resonance imaging (MRI): number of brain lesions in T2 weighted (T2w) sequence, number of brain black holes (T1 hypointensities) in T1 weighted sequence, number of spinal cord lesions in T2w sequence, number of brain and spinal cord lesions with gadolinium enhancement, distribution of brain lesions in T2w sequence (supratentorial and/or infratentorial), distribution of spinal cord lesions in T2w sequence (cervical and/or thoracic); and 5) data about prescribed treatments: choice of disease-modifying treatment, number of relapses before the beginning of treatment, switching of treatment and reason (refractory disease/ poor tolerance / pregnancy).

A relapse was defined as occurrence of new symptoms or exacerbation of existing symptoms persisting for at least 24 hours, in the absence of concurrent illness, and occurring at least 30 days after a previous relapse. Primary progressive multiple sclerosis was defined as the disease with at least 1 year of progression from its first clinical manifestation and with zero recorded relapses.

The study was conducted in accordance with the principles of the Declaration of Helsinki.

\section{Statistical analysis}

We performed descriptive analysis of demographic, clinical, laboratorial and neuroradiological data. Considering the low number of childhood-onset MS patients, we only performed descriptive analysis to compare the characteristics of childhood versus adolescent-onset MS patients. All analysis were performed with SPSS software.

\section{RESULTS}

We included 46 patients in our study, $72 \%$ (33) females and $28 \%$ (13) males, all of them white. The mean age of the first manifestation was 14 years and the mean age at confirmation of MS diagnosis was 16.1 years old. Six cases had childhood-onset and 40 cases had adolescence-onset. Mean time between the first manifestation and confirmation of the diagnosis was 27.3 months (ranging between 2 months and 19 years). Ninety-eight percent of the patients had been diagnosed with the relapsing-remitting MS (RRMS) form and only one patient had a primary progressive (PPMS) course. One patient had a positive family history of the disease, with her mother being the affected relative. The mean follow-up period in consultation for these patients was 8.9 years (ranging from 0 to 29 years). The Expanded Disability Status Scale (EDSS) score at diagnosis, assessed during a relapse, was 2 (between 0 and 4) whereas the median Expanded Disability Status Scale (EDSS) score in the last evaluation was 1 (between 0 and 7 ), assessed during a relapse or not (Table 1).

Intrathecal synthesis of $\mathrm{IgG}$ was evaluated in 35 patients, $74 \%$ of them had positive oligoclonal bands 
Table 1 - Patients data

\section{Characteristics}

Mean age of the first manifestation

Mean age at confirmation of MS diagnosis

$16.1 \mathrm{y}$

Mean time between the first manifestation and the diagnosis ( $\mathrm{min}-\mathrm{max}$ )

$27.3 \mathrm{~m}(2 \mathrm{~m}-19 \mathrm{y})$

n (\%)

Relapsing-remitting MS

$45(98 \%)$

Primary progressive MS

$1(2 \%)$

Family history of MS

$1(2 \%)$

Mean follow-up period in consultation

$8.9 y(0-29 y)$

Median EDSS score at diagnosis

$2(0-4)$

Median EDSS score in the last evaluation

$1(0-7)$

n (\%)

\section{Laboratory data}

CSF oligoclonal bands - Positive

IgG Index Increased

Pleocytosis - Yes

Positive serum VZV serologies

Positive serum HSV serologies

\section{Imaging data (First MRI)}

\section{Brain MRI}

Hyperintense cerebral lesions on T2-weighted lesions

- Supratentorial involvement

- Infratentorial involvement

Hypointense lesions on T1-weighted images ("black holes")

Contrast enhancing lesions on T1-weighted images

\section{Spinal MRI}

T2-hyperintense lesions spinal lesions

- Cervical segment

- Thoracic segment

Contrast enhancing lesions on T1-weighted images

First Immunomodulatory therapy

INF- $\beta$ 1a

INF- $\beta$ 1b

$11(24 \%)$

Glatiramer acetate

Other treatment

Change in therapy

Elevated number of relapses

Pregnancy

Intolerable side effects

$4(19 \%)$

n: Absolute number with proportions \% for nominal variables; m: Months; y: Year; VZV: Varicella-Zoster virus; HSV: Herpes Simplex Virus; EDSS: Expanded Disability Status Scale; Pleocytosis: CSF white cell count $>5$ cells $/ \mathrm{mm}^{3}$ 
and the $\operatorname{lgG}$ index was increased in $63 \%$ of the patients. Absence of pleocytosis (defined as a CSF white cell count of $>5$ cells $/ \mathrm{mm}^{3}$ ) was demonstrated in $70 \%$ of 33 patients studied for that item. Taking into account that demyelinating disease of the brain and spinal cord may follow viral infections (usually presenting as an acute disseminated encephalomyelitis-like event) and that viral infections may precede exacerbations of MS, some children (less than half) were evaluated for viral serologies in the workup of an episode of CNS inflammation. Serologies for the varicellazoster and the herpes-simplex viruses were negative in $88 \%$ and $77 \%$ of those patients, respectively (Table 1 ).

Regarding the imaging studies, we found that $95 \%$ of patients included in this study had T2-hyperintense lesions on the first brain MRI, with supratentorial involvement being present in $98 \%$ of the cases and infratentorial involvement in $59 \% .52 \%$ of the patients had hypointense lesions on T1-weighted images - "black holes"- which are a marker of axonal injury. Forty-four percent of the patients showed contrast enhancement on T1-weighted images, reflecting active inflammatory lesions. Regarding the spinal cord
MRI, 62\% (17 patients in 28) of the patients showed T2hyperintense lesions with the cervical segment being affected in $88 \%$ of the cases and the thoracic segment in $65 \%$. Thirty nine percent of the patients (7 in 18 patients) were shown to have contrast enhancing lesions (Table 1).

All the patients enrolled in the study underwent immunomodulatory therapy, mostly with INF- $\beta 1$ 1a (51\%), INF- $\beta 1 \mathrm{~b}(24 \%)$ and glatiramer acetate (13\%). In 22 patients $(48 \%)$ there was a change in the therapy throughout their follow-up, mostly because of increasing number of relapses, in $59 \%$ of the cases. The other reasons pointed were pregnancy $(23 \%)$ and intolerable side effects $(19 \%)$ (Table 1).

One of the goals of our study was to divide the patients into two groups according to the age of the first manifestation ( $<12$ or $\geq 12$ years). Six patients had the first manifestation before 12 years of age and were included in the childhood-onset group. $50 \%$ of these were females and none of the patients had familiar history of the disease. All of them had a relapsing-remitting form of MS. The remaining 40 patients were included in the adolescent-onset group,

Table 2 - Childhood-onset versus adolescent-onset data

\begin{tabular}{|c|c|c|c|c|}
\hline & \multicolumn{2}{|c|}{ Childhood-onset $(<12$ y) } & \multicolumn{2}{|c|}{ Adolescence-onset ( $\geq 12 \mathrm{y}$ ) } \\
\hline & $\mathbf{n}$ & $\begin{array}{c}\text { Median } \\
\text { (Min; max) }\end{array}$ & $\mathbf{n}$ & $\begin{array}{c}\text { Median } \\
\text { (Min; max) }\end{array}$ \\
\hline Age at confirmation diagnosis & 6 & 8.5 y $(5 y, 15 y)$ & 40 & 17.0 y $(12$ y, 33 y) \\
\hline Time between first manifestation and relapse & 5 & $12.0 \mathrm{~m}(2 \mathrm{~m}, 24 \mathrm{~m})$ & 35 & $12.0 \mathrm{~m}(2 \mathrm{~m}, 19 \mathrm{y})$ \\
\hline Time between first and last evaluation & 6 & 6,5 y $(0 y, 29 y)$ & 40 & $7.0 \mathrm{y}(0 \mathrm{y}, 25 \mathrm{y})$ \\
\hline EDSS at diagnosis & 5 & $2(1,3)$ & 33 & $2(0,4)$ \\
\hline \multirow[t]{2}{*}{ EDSS at last evaluation } & 6 & $1(0,2)$ & 39 & $1(0,7)$ \\
\hline & $\mathbf{N}$ & n (\%) & $\mathbf{N}$ & n (\%) \\
\hline CSF oligoclonal bands (Positive) & 4 & $3(75 \%)$ & 31 & $23(74 \%)$ \\
\hline Increased IgG index & 5 & $3(60 \%)$ & 30 & $19(63 \%)$ \\
\hline CSF Pleocytosis & 5 & $3(60 \%)$ & 28 & $7(25 \%)$ \\
\hline Positivity for serum VZV serologies & 3 & $1(33 \%)$ & 14 & $1(7 \%)$ \\
\hline Positivity for serum HSV serologies & 3 & 0 & 19 & $5(26 \%)$ \\
\hline Number of relapses until the beginning of treatment & 6 & 2 & 40 & 2 \\
\hline $\begin{array}{l}\text { Treatment options } \\
\text { INF- } \beta \text { 1a } \\
\text { INF- } \beta \text { 1b } \\
\text { Glatiramer acetate } \\
\text { Cyclophosphamide } \\
\text { Plasmapheresis } \\
\text { Natalizumab } \\
\text { Immunoglobulin } \\
\text { Azathioprine }\end{array}$ & 6 & $\begin{array}{c}4(66.8 \%) \\
0 \\
0 \\
1(16.6 \%) \\
1(16.6 \%) \\
0 \\
0 \\
0\end{array}$ & 40 & $\begin{array}{c}20(49 \%) \\
11(28 \%) \\
6(15 \%) \\
0 \\
0 \\
1(2.5 \%) \\
1(2.5 \%) \\
1(2.5 \%)\end{array}$ \\
\hline $\begin{array}{l}\text { Change in therapy } \\
\text { Elevated number of relapses } \\
\text { Pregnancy } \\
\text { Intolerance to therapy }\end{array}$ & 6 & $\begin{array}{c}2(33 \%) \\
2 \\
0 \\
0\end{array}$ & 40 & $\begin{aligned} & 20(50 \%) \\
& 3(15 \%) \\
& 11(55 \%) \\
& 0\end{aligned}$ \\
\hline
\end{tabular}

N: Number of total patients analysed; n: Absolute number with proportions (\%) for nominal variables; m: Months; y: Years; VZV: Varicella-Zoster Virus; HSV: Herpes Simplex Virus; EDSS: Expanded Disability Status Scale; Pleocytosis: CSF white cell count $>5$ cells $/ \mathrm{mm}^{3}$ 
$75 \%$ of which being females. The course of the disease was relapsing-remitting in $97.5 \%$ of patients. The mean age at confirmation of MS diagnosis in this group was 17.0 years with a mean time of 12.0 months between disease onset and the next relapse (Table 2).

Imaging data and the average number of relapses until the beginning of treatment (about 2 relapses) were very similar in both groups.

In the childhood-onset group (6 patients), 4 of the patients underwent treatment with INF- $\beta 1$ a and 1 with cyclophosphamide. The other patient only received plasmapheresis for acute relapse. In the adolescentonset group, $49 \%$ of the patients initiated therapy with INF- $\beta 1 \mathrm{a}, 28 \%$ INF- $\beta 1 \mathrm{~b}$ and $15 \%$ with glatiramer acetate. Three patients underwent treatment with natalizumab, immunoglobulin and azathioprine, as initial therapy. In two of the six patients of the childhood-onset group, there was a change in the therapy justified, in both cases, by an elevated number of relapses. In the other group, about $50 \%$ changed therapy, $15 \%$ of those for the reason stated above. Pregnancy was responsible for change of treatment in 55\% of the cases (Table 2), but this situation only occurred after adulthood was reached.

\section{DISCUSSION}

Pediatric MS is a rare entity, childhood-onset forms being particularly rare. Accordingly, we found only 6 cases with disease onset before 12 years of age (13\% of all the patients). This is in agreement with previously published reports, estimating that $17 \%$ of pediatric MS patients were under the age of 10 years old at the disease onset. ${ }^{2}$

An article by Peña et al, $^{7}$ referring to pediatric age, reported a ratio of 1 female: 1 male, when symptoms began before ten years old and 3 female: 1 male, when after 12 years old. This ratio is similar to what we found in our study suggesting a role for pubertal hormonal mechanisms that may influence the manifestation of the disease. A previous Portuguese study focusing on this question found a prevalence of $59 \%$ female patients under 21 years old. ${ }^{5}$

We only found one patient with PPMS, with disease onset during adolescence and severe disability at the time of the last evaluation. The overall preponderance of RRMS forms in our study is higher than the $80 \%$ reported in adult-onset MS, which is in agreement with the literature. ${ }^{2}$ Also a previous monocentric Portuguese study found a uniformity of RRMS forms under the age of 21 years old. ${ }^{5}$ The natural history of pediatric MS may differ from the adult form of disease, which might be explained by more intense inflammatory reaction in pediatric MS, especially among young children. ${ }^{8}$

We identified a sole patient who had familial history of MS. Previous studies ${ }^{1,3,7}$ reported a proportion of $6-13.5 \%$ of patients with pediatric MS with a known family history, suggesting that familiar MS is not more frequent among pediatric patients. Furthermore, a previous study found that genetic load (familial versus sporadic cases) did not generally influence the age of $\mathrm{MS} .^{9}$
In our study, mean time from the first manifestation of MS to the next relapse in both age groups (children and adolescents) was 12 months, in agreement with a previous Portuguese study. ${ }^{5}$ Other studies had varied results. In a larger study, ${ }^{3}$ the estimated median time from the onset of MS to the second neurologic episode was 2 years among pediatric MS patients and it did not differ significantly from adult onset patients. Another study found a median first interattack interval of 5.6 months and an annualized relapse rate of 1.13 among pediatric MS patients (versus 13.8 months and 0.4 relapses/year, respectively, among adult patients), suggesting that younger patients experience a highly inflammatory disease course. ${ }^{10}$

In our work, the mean time between the first manifestation of the disease and the diagnosis was 27.3 months, which is longer than expected. However, this result was highly influenced by a single outlier, who had an interattack interval of 19 years.

Regarding the disability and progression of the disease (based on Expanded Disability Status Scale (EDSS) assessments), we found a lower EDSS score at the time of the last evaluation, when compared to that registered at the time of onset. This may be attributed to the efficacy of immunomodulatory treatments, that have been started earlier in this study when compared to others, ${ }^{11}$ and to the timing of first EDSS assessment, frequently evaluated during a relapse. On the other hand, this finding may also be due to the fact that the majority of patients have a short follow-up time. Some previous studies suggested that most children with RRMS remain with mild motor disability, ${ }^{7}$ but others also highlighted the unpredictability of progression patterns in pediatric MS, with several reports of gradual and important progression. ${ }^{8}$

We have found CSF pleocytosis in $60 \%$ of the childhoodonset group and in $25 \%$ of the adolescent group. Despite the fact that our small group of patients does not allow the establishment of definite conclusions, these findings are in line with those previously reported by Pohl et al, ${ }^{13}$ regarding the importance of this marker in early-onset MS. CSF positivity for oligoclonal bands was present in $74 \%$ of patients, which is inferior to the one reported in adults ( 98\%). Data pertaining to CSF studies is less conclusive than in adults, making it slightly less useful as an aid to the differential diagnosis, which contributes to the complexity of the diagnosis of MS in children and adolescents. In adults, an elevated immunoglobulin $\mathrm{G}(\mathrm{lgG})$ index or the presence of cerebrospinal fluid (CSF) restricted IgG oligoclonal bands are biologic hallmarks of MS. The percentage of pediatric MS patients with oligoclonal bands, an elevated IgG index or pleocytosis varies widely. A study demonstrated that earlier-onset pediatric MS patients (onset < 11 years) may have a distinct CSF inflammatory profile at disease presentation consisting of neutrophilic pleocytosis and normal IgG index. ${ }^{14}$

We have found that a significant number of patients had MRI evidence of spinal cord lesions (in $50 \%$ on childhoodonset and $63 \%$ on adolescence-onset group). Nevertheless 
we were not able to assess the volume of these lesions in order to establish a valid comparison, due to the fact that only routine MRI sequences were performed. The MRI presentation of pediatric MS may differ from the adult disease. Brain lesions in younger children (age $<11$ years) may be large with poorly defined borders and the lesions are frequently confluent at the onset of disease. A significant number of these lesions may vanish on followup imaging. On the other hand, late-onset pediatric patients have an MRI phenotype that is more similar to adults. ${ }^{15}$ The MRI studies have shown a higher T2 burden in children with MS compared with adults, especially in the brainstem and cerebellum. Children with MS are more likely than adults to have T2 and T1 lesions in the infratentorial white matter, raising the possibility of preferential immune targeting of more mature myelin. Children with MS tend to have a lower supratentorial T1 lesion burden, possibly reflecting a more effective remyelination and repair in brain regions still engaged in active primary myelination. ${ }^{17}$

To our knowledge, there are no available controlled studies regarding the efficacy of immunomodulatory treatments in this age group ${ }^{12}$ and use of these treatments is mostly based on retrospective, observational studies. In our patients, there was a global preference for the best known, and longer in use, interferons and glatiramer acetate. This may be attributed to the longer experience of doctors in the use of these drugs. The majority of studies demonstrated a reduction in relapse rate after the initiation of first-line treatments. ${ }^{18}$ Nevertheless, some children continue to experience breakthrough disease. In a study of pediatric MS patients, $44.2 \%$ switched to another first or second-line therapy because of refractory disease (27.9\%) or poor tolerance or noncompliance $(16.3 \%)$, during a mean observational period of 3.9 years. ${ }^{19}$ Second-line treatments could have an important role in the management of pediatric MS. Available data in children with MS who did not respond to initial immunomodulatory treatments, suggest that natalizumab, in most cases, reduces clinical and MRI relapses but the risk profile must be balanced against potential benefits. ${ }^{20,21}$ Concerning fingolimod, data is sparse regarding safety, tolerability and optimal dosing in children. Cyclophosphamide reduced relapse rate and halted disease progression in the majority of cases in a study of pediatric MS patients with inadequate treatment response to other immunosuppressive-immunomodulatory treatments but there is a risk of serious side effects. ${ }^{22}$ In our patients, the decision to switch immunomodulatory drugs, due to treatment failure, was based on clinical and imaging data and the perception of disease progression.

\section{CONCLUSION}

In conclusion, our study provides new data on pediatric MS characteristics in Portugal and, to our knowledge, this is the first multicentric study attempting to characterize this population in this country. For the last few years a number of studies have been published regarding pediatric MS and our results are similar to previously reported data in other parts of the world. Childhood and adolescence MS has different characteristics from those identified in adults, rendering the diagnosis difficult and intricate and requiring dedicated professionals involved in its diagnosis and management. The mechanisms underlying pediatric MS particularities are largely unknown, as key questions in the pathobiology of the disease remain unanswered. Additional investigations are still required to further understand the immunobiology of pediatric MS and move forward in the field.

\section{ACKNOWLEDGEMENTS}

We gratefully acknowledge José Vale and Maria José Sá for their expert support and critical reviewing of this manuscript. We also would like to thank the Portuguese Group of Multiple Sclerosis for the support of the initiative; Mário Veloso, José Vale, Pedro Cabral, José Carlos Ferreira, Miguel Viana Baptista, Isabel Carmo, Sofia Calado, Nuno Canas, Maria José Sá, Pedro Abreu, Joana Guimarães, Teresa Mendonça, Jorge Reis, Grilo Gonçalves, Carla Cecília Nunes, Isabel Fineza, Carmen Costa, Mónica Vasconcelos, Rui Pedrosa and Armando Sena - the Neurologists and Pediatricians involved in the diagnosis and management of the included patients; and Forpoint for providing the technical support of the study.

\section{PROTECTION OF HUMANS AND ANIMALS}

The authors declare that the procedures were followed according to the regulations established by the Clinical Research and Ethics Committee and to the Helsinki Declaration of the World Medical Association.

\section{DATA CONFIDENTIALITY}

The authors declare having followed the protocols in use at their working center regarding patient's data publication.

\section{CONFLICTING INTERESTS}

The authors declare no potential conflicts of interest with respect to the authorship and/or publication of this article.

\section{FINANCIAL DISCLOSURE / FUNDING}

The statistical analysis was performed by Forpoint with funding by Biogen Idec. The founding source had no role in data collection and interpretation, or writing of the report. The authors received no financial support for the authorship of this article.

\section{REFERENCES}

1. Simone IL, Carrara D, Tortorella C, Liguori M, Lepore V, Pellegrini F, et al. Course and prognosis in early-onset MS: comparison with adultonset forms. Neurology. 2002;59:1922-8.
2. Banwell B, Ghezzi A, Bar-Or A, Mikaeloff Y, Tardieu M. Multiple sclerosis in children: clinical diagnosis, therapeutic strategies, and future directions. Lancet Neurol. 2007;6:887-902. 
3. Renoux C, Vukusic S, Mikaeloff Y, Edan G, Clanet M, Dubois B, et al. Adult Neurology Departments KIDMUS Study Group. Natural history of multiple sclerosis with childhood onset. N Engl J Med. 2007;356:260313

4. de Sá J, Alcalde-Cabero E, Almazán-Isla J, Sempere A, de PedroCuesta. Capture-recapture as a potentially useful procedure for assessing prevalence of multiple sclerosis: methodologic exercise using Portuguese data. Neuroepidemiology. 2012;38:209-16.

5. Silva A, Sá MJ. Esclerosis múltiple de inicio juvenil. Rev Neurol. 1999;28:1036-40.

6. Krupp LB, Banwell B, Tenembaum S, International Pediatric MS Study Group. Consensus definitions proposed for pediatric multiple sclerosis and related disorders. Neurology. 2007;68:S7-12.

7. Peña JA, Montiel-Nava C, Ravela ME, González S, La Cruz EM. Esclerosis múltiple en niños; Clarificando su Ubicación dentro del espectro desmielinizante. Invest Clin. 2006;47:413-25.

8. Boiko A, Vorobeychik G, Paty D, Devonshire V, Sadovnick D. University of British Columbia MS Clinic Neurologists. Early onset multiple sclerosis: a longitudinal study. Neurology. 2002;59:1006-10.

9. Sadovnick AD, Yee IM, Guimond C, Reis J, Dyment DA, Ebers GC Age of onset in concordant twins and other relative pairs with multiple sclerosis. Am J Epidemiol. 2009;170:289-96.

10. Gorman MP, Healy BC, Polgar-Turcsanyi M, Chitnis T. Increased relapse rate in pediatric-onset compared with adult-onset multiple sclerosis. Arch Neurol. 2009;66:54-9.

11. Pohl D, Waubant E, Banwell B, Chabas D, Chitnis T, WeinstockGuttman B, et al. Treatment of pediatric multiple sclerosis and variants. Neurology. 2007;68:S54

12. Chitnis T. Disease-modifying therapy of pediatric multiple sclerosis. Neurotherapeutics. 2013;10:89-96.

13. Pohl D, Rostasy K, Reiber H, Hanefeld F. CSF characteristics in early onset multiple sclerosis. Neurology. 2004;63:966-7.
14. Chabas D, Ness J, Belman A, Yeh EA, Kuntz N, Gorman MP, et al. US Network of Pediatric MS Centers of Excellence. Younger children with MS have a distinct CSF inflammatory profile at onset. Neurology. 2010;74:399-405.

15. Chabas D, Castillo-Trivino T, Mowry EM, Strober JB, Glenn OA Waubant E. Vanishing MS T2-bright lesions before puberty: a distinct MRI phenotype? Neurology. 2008;71:1090-3.

16. Yeh EA, Weinstock-Guttman B, Ramanathan M, Ramasamy DP, Willis $\mathrm{L}$, Cox JL, et al. Magnetic resonance imaging characteristics of children and adults with pediatric-onset multiple sclerosis. Brain. 2009;132:3392400.

17. Waubant E, Chabas D, Okuda DT, Glenn O, Mowry E, Henry RG, et al. Difference in disease burden and activity in pediatric patients on brain magnetic resonance imaging at time of multiple sclerosis onset vs adults. Arch Neurol.2009;66:967-71.

18. Chitnis T, Tenembaum S, Banwell B, Krupp L, Pohl D, Rostasy K, et al. International Pediatric Multiple Sclerosis Study Group. Consensus statement: evaluation of new and existing therapeutics for pediatric multiple sclerosis. Mult Scler. 2012;18:116-27.

19. Yeh EA, Waubant E, Krupp LB, Ness J, Chitnis T, Kuntz N, et al. Multiple sclerosis therapies in pediatric patients with refractory multiple sclerosis. Arch Neurol. 2011;68:437-44.

20. Huppke P, Stark W, Zürcher C, Huppke B, Brück W, Gärtner J. Natalizumab use in pediatric multiple sclerosis. Arch Neurol. 2008;65:1655-8

21. Arnal-Garcia C, García-Montero MR, Málaga I, Millán-Pascual J, OlivaNacarino P, Ramió-Torrentà L, et al. Natalizumab use in pediatric patients with relapsing-remitting multiple sclerosis. Eur J Paediatr Neurol. 2013;17:50-4.

22. Makhani N, Gorman MP, Branson HM, Stazzone L, Banwell BL, Chitnis T. Cyclophosphamide therapy in pediatric multiple sclerosis. Neurology 2009;72:2076-82. 